Journal Of Al-Azhar University Engineering Sector

Vol. 14, No. 51, April, 2019, 613-625

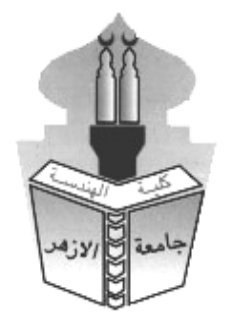

\title{
THE IMPACT OF USING SEMI-TRANSPARENT PHOTOVOLTAIC IN OFFICE BUILDING FACADES ON IMPROVING INDOOR THERMAL PERFORMANCE IN EGYPT
}

\author{
Ahmed Atef El Desoky Faggal, Amal Kamal Mohamed Shams Eldin \\ and Rana Nageeb EI Sayed Ali \\ Architectural engineer, Faculty of Engineering, Ain Shams University.
}

\begin{abstract}
This research dealt with semi-transparent photovoltaic STPV as a substitution material of the transparent parts of office building envelope. Integrating STPV in facades especially in the transparent parts plays a major role in improving the thermal performance due to its impact on reducing the amount of solar heat gain thus reducing cooling loads in addition to not having any negative consequences on the environment. As a result, it is trigger for STPV to be integrated in office building facades especially that in these buildings 51-59\% of total energy consumption is for achieving the visual and thermal comfort [1]. This is due to the extensive depending on utilization of mechanical methods in achieving the indoor thermal comfort. As a result of the over consumption of energy in achieving the thermal comfort, the situation of energy crisis that Egypt is facing nowadays became more worse in addition to increasing the level of pollution and carbon emissions.

This paper assesses the thermal performance of STPV integrated in office building facades through simulation conducted with Design builder software. The thermal performance of STPV is evaluated by investigating the efficient design of STPV through different parameters. These parameters are window to wall ratio WWR and visible light transmittance VLT, with taking into account the impact of using lighting control system. It is obtained, as a result of this study, that integrating STPV in office building facades could save almost half of cooling loads regardless of the difference in climatic conditions over the investigated three climatic regions in Egypt.
\end{abstract}

\section{Key Words: Renewable Energy, Semi-transparent photovoltaic, Thermal performance,} Solar heat gain, Office buildings.

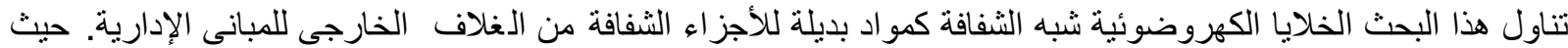

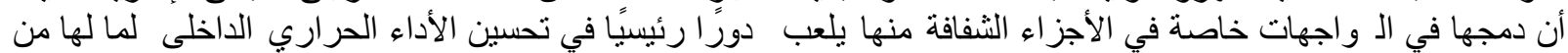

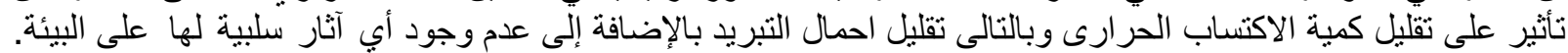

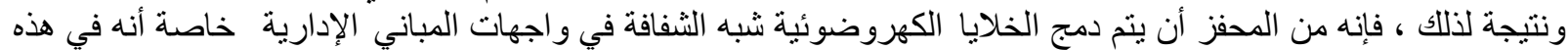

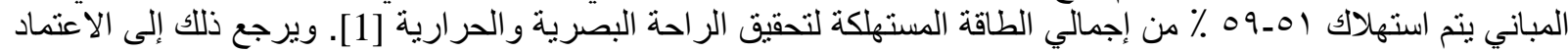

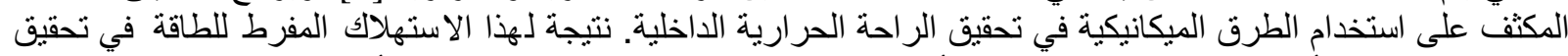

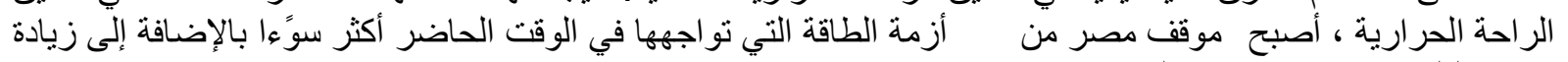
مستوى التلوث وزيادة انبعاثات الكربون. 


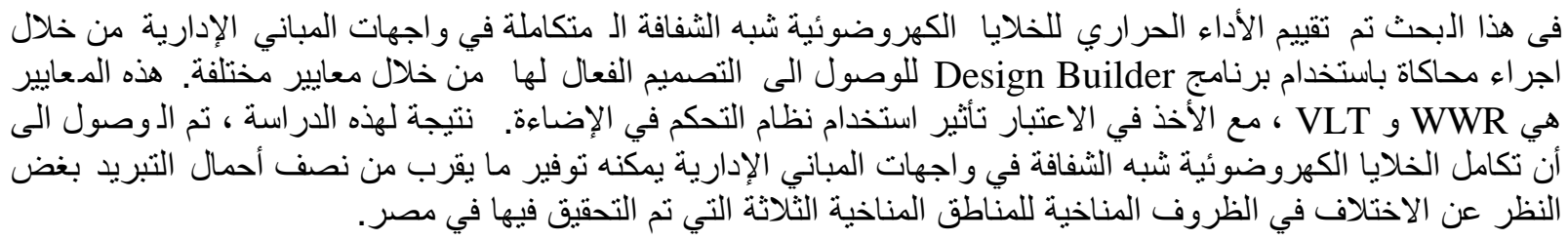

\section{INTRODUCTION}

The most dangerous issue facing Egypt nowadays is the energy crisis. The rate of energy consumption in Egypt grew significantly within the last two decades until it exceeded 165\% [2]. The main factor caused this significant increase of the energy consumption in Egypt is trying to compensate the negative consequences of industrial revolution in terms of indoor thermal comfort. During the industrial revolution the higher availability of glass besides new construction materials such as steel and concrete allowed larger glazed areas to be realized in building envelopes. Highly glazed buildings; which are a development of the daylight architecture in moderate climates, have become a world-wide standard for non-domestic constructions such as offices. Consequently, they revealed negative effects on indoor thermal comfort in regions of hot climate. It was difficult to keep heat in winter and buildings became more vulnerable to overheat in summer. As a result of that, achieving the indoor thermal comfort became depending mainly on the extensive utilization of mechanical methods thus causing over consumption of energy [3].

Due to that, improving the energy performance in highly glazed building became challenging. As façade is the mediator between the indoor and outdoor environment, optimizing the building envelope design will control the overconsumption of energy to accomplish thermal comfort. One of the most promising technologies that could be integrated into the building envelope to improve the indoor thermal performance is semi-transparent photovoltaic STPV technology [4].

Integrating STPV in office buildings façade might cause summer overheating besides glare problems, due to penetration of solar radiation, if inappropriately designed [5]. Consequently, it needs to investigate its efficient design that could improve the indoor thermal performance by providing the highest cooling/heating savings.

Current studies in this area includes assessment of the thermal performance of STPV, as a part of overall energy performance, through investigating many parameters such as window to wall ratio WWR, Visible light transmittance VLT and orientation. In Singapore, it is used the simulation tool Energy Plus to examine six commercially available amorphous silicon STPV elements to evaluate the overall energy performance. The results revealed that STPV glazing solutions can save energy with rate between 17 and $41 \%$ compared to conventional window glazing for large façade openings from 70-100\% WWR [6]. However, in Hong Kong, the overall energy performance of STPV glazing window is investigated by integrating the simulation results of thermal, power, and visual behaviors. The main finding of the work was that among five investigated orientations, south-east is the optimal orientation for overall energy [7]. In Madrid, it is found that all investigated STPV elements with visible transmittances from 0 to $40 \%$ can improve the building energy efficiency compared to the regular glass (RG) solution. They can provide an energy balance index (EBI) reduction ranging between $22 \%$ (for element 40) and 32 $\%$ (for element 20) [8]. While in Tokyo, The results of simulation showed that VLT of $40 \%$ and WWR of 50\% achieved the minimum energy consumption in the building when artificial lighting was controlled with daylighting [9].

Therefore, there is still a lack of research on the thermal performance of STPV through finding efficient WWR and VLT in Egypt's climate where the cooling loads became high almost throughout the whole year. This study aims to find the efficient design of STPV; WWR and VLT, that could accomplish the highest cooling savings in Egypt's climate with taking into account the effect of using the artificial lighting control system. 


\section{Profile of Egypt's climate}

Egypt lies in dry arid region according to the world climatic classification [10]. Solar energy is abundant in Egypt. It enjoys solar irradiation ranging from 2000-3200 kwh/m2/y. The sun shine duration is around 9-11 h/day as per Egypt's distinguishing position in the Sun Belt area [11]. However, the desert conditions that are prevailing in Egypt also result in high summer temperatures and high levels of dust, both of them have negative consequences on solar technologies. They could lead to rapidly deterioration for solar energy appliances. Although these challenges, solar technologies could be deployed widely throughout Egypt. [12].

Egypt is divided into eight climatic regions; Northern coast, Cairo and Delta, North upper, South upper, Eastern coast, Highlands, Desert and South Egypt. Each climatic region has different characteristics [10]. For this research, Cairo in Cairo and Delta region, Alexandria in Northern coast region and Aswan in South Egypt region, are chosen to investigate the thermal performance of Semi-transparent photovoltaic (STPV) integrated in office building facades. Those three regions are chosen as each region has its own climatic conditions that differ from the other regions. Each region differs in humidity, temperatures average and the amount of precipitation (rain, snow etc.). It can be noticed clearly that Aswan has the highest temperature average and the lowest humidity ratio while Alexandria has the lowest temperature average and the highest humidity ratio. Cairo is the medium condition between Aswan and Alexandria [13].

\section{Research methodology}

Computer simulation is conducted for this research to reach to the maximum thermal savings when semi-transparent photovoltaic STPV integrated in Office building facades. To run the simulation, Design builder software as a graphical interface with Energy plus 4.0 as a simulation engine are used. Energy plus is building energy simulation program having the capabilities for modeling building heating, cooling and lighting loads besides other energy flows [14]. Figure 4.1 illustrates steps of simulation performed. The model used in simulation should be defined through many points such as geometry, climatic conditions and façade properties. This study needs to identify the specifications of STPV modules used in simulation. The investigated STPV modules are integrated in the southern façade by window to wall ratios (WWRs) $10 \%-100 \%$ and different visible light transmittances (VLTs) $10 \%-40 \%$ with taking into account the impact of using artificial lighting control system. All obtained results will be compared with the results in case of using conventional glazing which is selected to be single clear glass ( $\mathrm{Sgl} \mathrm{Clr}$ glass).

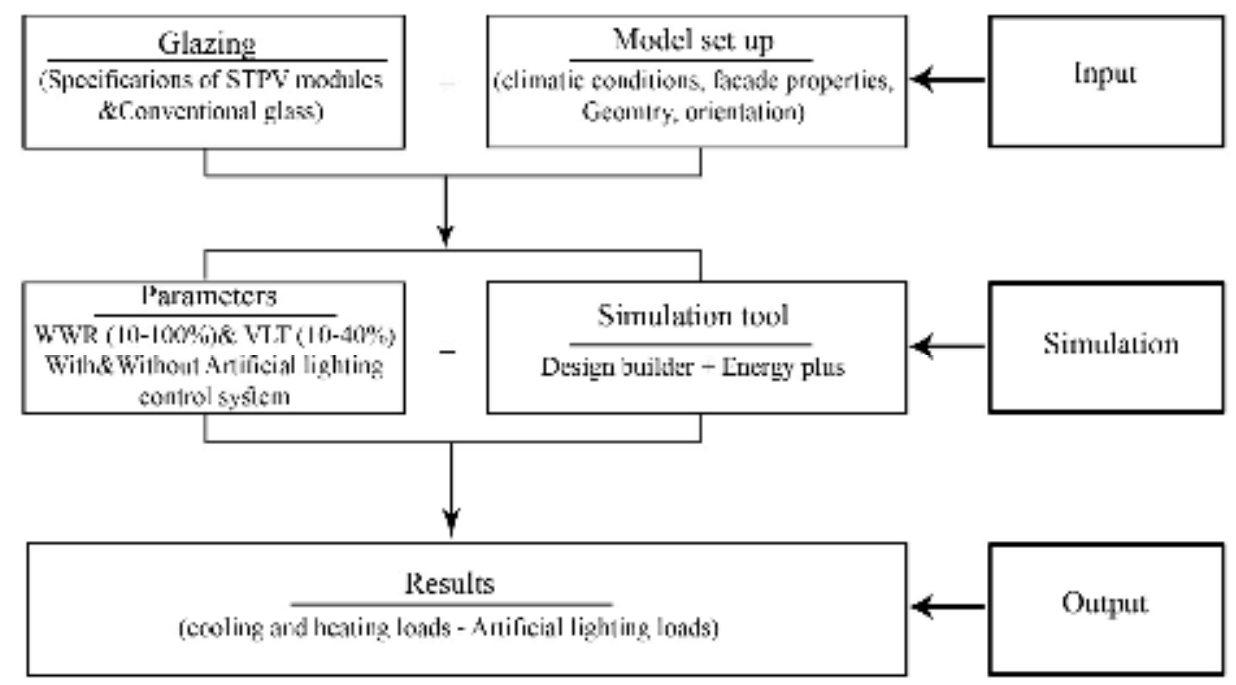

Figure 4.1 Methodology steps 


\section{MODEL SET UP}

The model that is used in simulation is an office room in a hypothetical office building of simple design having a rectangular typical floor plan. This office building consists of offices zones are distributed around service core in the middle of the floor. Its facades are facing the four main orientations; north, south, east and west. It is selected an office room with dimension of $5 \mathrm{~m} * 5 \mathrm{~m}$ in the southern orientation to run the simulation. The internal walls for the simulated office room were assumed to be adiabatic to prevent heat transfer in between so that each perimeter zone can be accurately analyzed. Figure 0.1 shows the simulated office room selected in typical floor of the hypothetical office building.

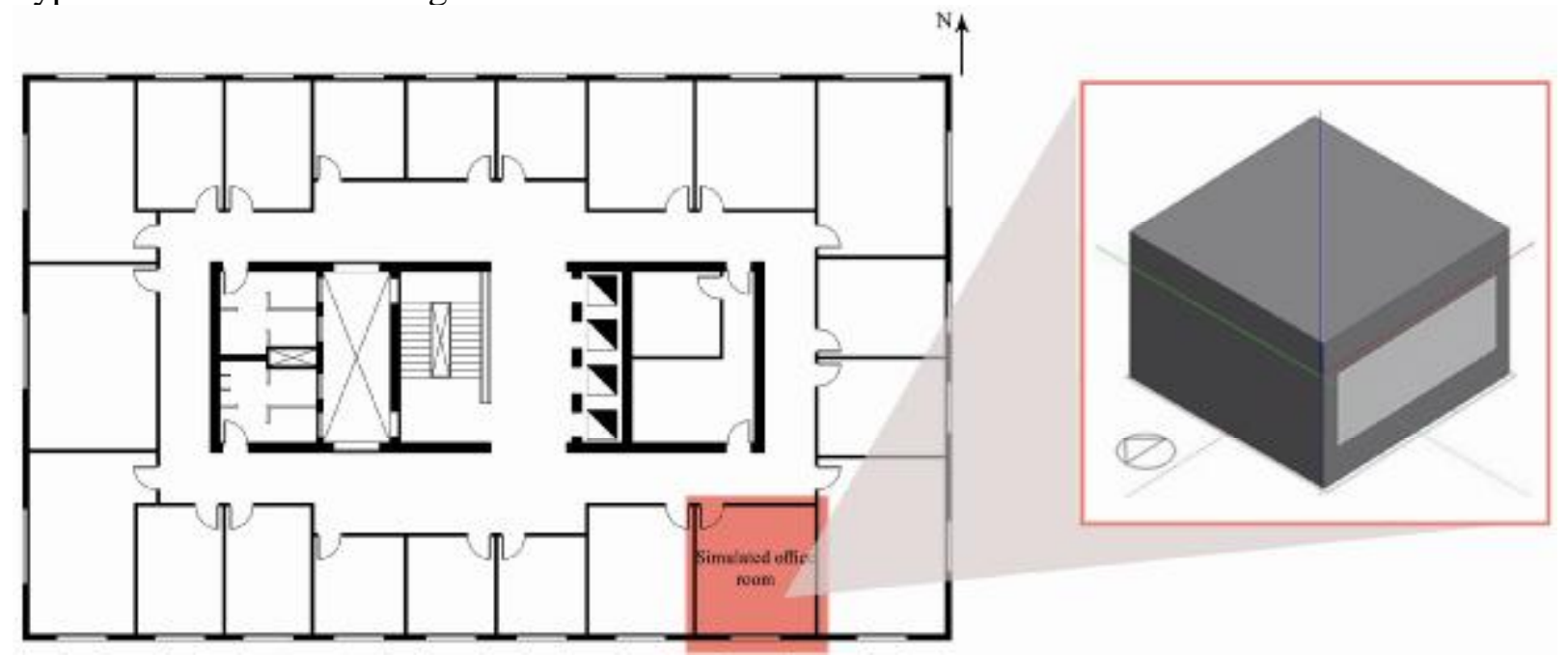

Figure 0.1 hypothetical office room used in simulation

The internal heat gains and building construction details are shown in Table 0.1and Table 0.1, respectively. Also time schedule for occupants and the percent variation in lighting and equipment using is shown in

Table 0.1. The construction details values used in simulation adhered to the Energy efficient code (ECP 306 - 2005 / 2005 - Code 306) part 2 for commercial buildings (306/2).

Table 0.1 Design values for internal heat gains

\begin{tabular}{|c|c|}
\hline Orientation & South \\
\hline Total simulated area & $5 * 5=25 \mathrm{~m}^{2}$ \\
\hline Clear height & $3 \mathbf{m}$ \\
\hline Window - to - wall ratio (WWR) & $10-100 \%$ \\
\hline Transmittance degree & $10-40 \%$ \\
\hline Illuminance set point & 500 lux \\
\hline HVAC temperature set point & $24 \mathrm{c}$ \\
\hline Heating temperature set point & $22 \mathrm{c}$ \\
\hline Occupancy & (4 persons; 3 men and 1 woman) 0.16 person $/ \mathrm{m} 2$ \\
\hline Lighting density & $\begin{array}{l}\text { 6.4 W/m2 (by using } 4 \text { lamps each lamp } \\
\text { consumes } 40 \text { watt/hour) }\end{array}$ \\
\hline Lighting control type & Stepped (2 steps) \\
\hline Equipment (1) & $\begin{array}{l}\text { The office room contains } 4 \text { lab tops each one } \\
\text { consumes } 65 \mathrm{watt} / \mathrm{hour}\end{array}$ \\
\hline Equipment (2) & $\begin{array}{l}\text { The office room contains } 1 \text { printer ( } 381 \\
\text { watt/hour) }\end{array}$ \\
\hline
\end{tabular}


THE IMPACT OF USING SEMI-TRANSPARENT PHOTOVOLTAIC IN OFFICE BUILDING FACADES ON IMPROVING INDOOR THERMAL PERFORMANCE IN EGYPT

The aspect ratio of window was 1:2 for all window-to-wall ratios (WWRs), similar to the lengthto height ratio of the external building. A split with no fresh air cooling system with a coefficient of cooling performance (COP) of 1.83 was chosen for the building.

Table 0.1 Construction details of office room used in simulation

\begin{tabular}{|l|c|c|c|c|}
\hline Layers (outer to inner) & $\begin{array}{c}\text { Thermal conductivity } \\
{[\mathrm{W} /(\mathrm{m} \cdot \mathrm{K})]}\end{array}$ & $\begin{array}{c}\text { Density } \\
{[\mathrm{kg} / \mathrm{m} 3]}\end{array}$ & $\begin{array}{c}\text { Specific heat } \\
{[\mathrm{J} /(\mathrm{kg} \cdot \mathrm{K})]}\end{array}$ & $\begin{array}{c}\text { Thickness } \\
{[\mathrm{cm}]}\end{array}$ \\
\hline Exterior walls & \multicolumn{4}{|l|}{} \\
\hline 1- Cement mortar & 0.88 & 2800 & 896 & 2 \\
\hline 2- Solid cement brick & 0.840 & 1700 & 800 & 25 \\
\hline 3- Cement mortar & 0.88 & 2800 & 896 & 2 \\
\hline Interior walls & are assumed to be adiabatic \\
\hline Floor & is assumed to be adiabatic \\
\hline Ceiling & is assumed to be adiabatic \\
\hline
\end{tabular}

Table 0.1 Time schedule for occupants and the percent variation in lighting and equipment using

\begin{tabular}{|c|c|c|c|c|}
\hline & Occupants (\%) & Lighting (\%) & $\begin{array}{c}\text { Equipment (lab } \\
\text { tops \%) }\end{array}$ & $\begin{array}{c}\text { Equipment (printer } \\
\%)\end{array}$ \\
\hline $0-8 \mathrm{hr}$ & $0 \%$ & $0 \%$ & $0 \%$ & $0 \%$ \\
\hline $8-9 \mathrm{hr}$ & $0 \%$ & $30 \%$ & $0 \%$ & $0 \%$ \\
\hline $9-10 \mathrm{hr}$ & $90 \%$ & $90 \%$ & $90 \%$ & $90 \%$ \\
\hline $10-13 \mathrm{hr}$ & $95 \%$ & $90 \%$ & $95 \%$ & $90 \%$ \\
\hline $13-14 \mathrm{hr}$ & $50 \%$ & $90 \%$ & $50 \%$ & $30 \%$ \\
\hline $14-18 \mathrm{hr}$ & $95 \%$ & $90 \%$ & $95 \%$ & $90 \%$ \\
\hline $18-19 \mathrm{hr}$ & $30 \%$ & $50 \%$ & $30 \%$ & $10 \%$ \\
\hline $19-20 \mathrm{hr}$ & $10 \%$ & $40 \%$ & $10 \%$ & $30 \%$ \\
\hline $20-24 \mathrm{hr}$ & $0 \%$ & $0 \%$ & $0 \%$ & $0 \%$ \\
\hline
\end{tabular}

Commercially available STPV modules are selected to run the simulation [8]. They are made from amorphous silicon (a-Si) with visible light transmittance range from $10 \%$ to $40 \%$. The specifications of selected STPV modules needed for the simulation are presented in

Table 0.1; visible light transmittance degree and thermal properties (u-value and SHGC), in addition to specifications of single clear glass ( $\mathrm{Sgl} \mathrm{Clr}$ glass).

Table 0.1 Specifications of the selected Semi-transparent photovoltaic

\begin{tabular}{|c|c|c|c|c|c|}
\hline Number & PV tech & $\begin{array}{c}\text { Thickness } \\
\mathrm{mm}\end{array}$ & $\begin{array}{c}\text { VLT } \\
\%\end{array}$ & $\begin{array}{c}\text { U- value } \\
\mathrm{W} / \mathrm{m}^{2} \mathrm{~K}\end{array}$ & $\begin{array}{c}\text { SHGC } \\
\%\end{array}$ \\
\hline 1 & $\mathrm{a}-\mathrm{si}$ & 21 & $10 \%$ & 2.783 & 0.216 \\
\hline 2 & $\mathrm{a}-\mathrm{si}$ & 21 & $20 \%$ & 2.783 & 0.253 \\
\hline 3 & $\mathrm{a}-\mathrm{si}$ & 21 & $30 \%$ & 2.783 & 0.316 \\
\hline 4 & $\mathrm{a}-\mathrm{si}$ & 21 & $40 \%$ & 2.783 & 0.367 \\
\hline Sgl Clr 3mm & - & 3 & $88 \%$ & 6.121 & 0.81 \\
\hline
\end{tabular}


THE IMPACT OF USING SEMI-TRANSPARENT PHOTOVOLTAIC IN OFFICE BUILDING FACADES ON IMPROVING INDOOR THERMAL PERFORMANCE IN EGYPT

\section{RESULTS AND DISCUSSION}

The obtained results are divided into two cases for all investigated three regions chosen for simulation; Cairo, Alexandria, Aswan. Those two cases are:

1- Case (A): without using artificial lighting control system.

2- Case (B): with using artificial lighting control systems.

One of the important results observed in both cases is that the heating demand can be considered negligible due to that the values of heating loads obtained are barely visible.

\subsection{Case (A) without using lighting control system}

From Figure 0.1 that shows the results of cooling loads for semi-transparent photovoltaic modules compared to single clear glass in all investigated three regions in case of not using artificial lighting control system, critical results for this case are obtained:
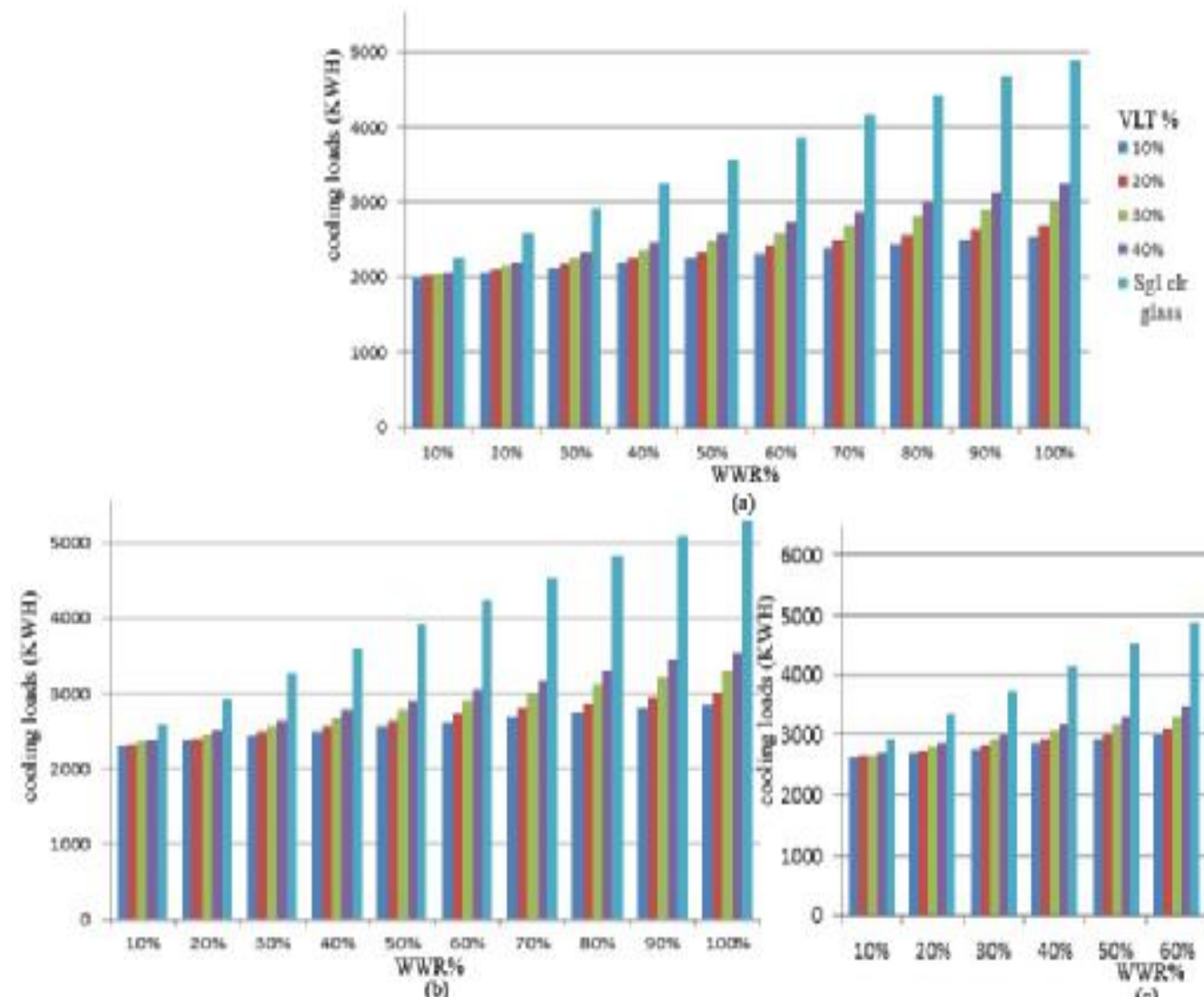

)

Figure 0.1 Cooling loads in case of not using artificial lighting control system in three regions: (a) Alexandria, (b) Cairo and (c) Aswan.

1- Increasing visible light transmittance (VLT) of glazing elements increases the cooling demand because the solar heat gains became higher.

2- Increasing window to wall ratio (WWR) of glazing elements increases the cooling demand because the solar heat gains became higher.

3- Critical results are accomplished in all three investigated regions; Cairo, Alexandria and Aswan, by the same combination of semi-transparent photovoltaic (STPV) despite of the difference in climatic conditions for investigated three regions.

4- It is noticed clearly that there isn't any STPV glazing element which is not appropriate to be used. All investigated STPV glazing elements can improve the thermal performance. 
THE IMPACT OF USING SEMI-TRANSPARENT PHOTOVOLTAIC IN OFFICE BUILDING FACADES ON IMPROVING INDOOR THERMAL PERFORMANCE IN EGYPT

5- STPV10\% with WWR $=10 \%$, accomplished the lowest cooling loads in all three regions. Its cooling performance is more efficient in Alexandria than in Cairo and Aswan. It can save $10 \%, 11 \%$ and $10.2 \%$ in Cairo, Alexandria and Aswan respectively. While STPV $40 \%$ with WWR $=100 \%$ achieved the highest cooling load. It is noticed also that it is more efficient to be used in Aswan than Alexandria and Cairo.it can save 33.1\%, 33.8\% and $34.1 \%$ in Cairo, Alexandria and Aswan respectively.

6- The lowest cooling energy saving is obtained by STPV $40 \%$ with WWR $=10 \%$ in all three regions. This element is more efficient in Alexandria than Cairo and Aswan. It can save 7.6\%, 8.4\% and $7.9 \%$ in Cairo, Alexandria and Aswan respectively. While the highest cooling energy saving is obtained by STPV $10 \%$ with WWR $=100 \%$. This element is also more efficient in Alexandria than Cairo and Aswan. It can save 46.3\%, 48\% and $46.6 \%$ in Cairo, Alexandria and Aswan respectively. As a result of what mentioned before, implementing STPV with the lowest VLT and the highest WWR can save almost half the cooling loads.

\subsection{Case (B) with using lighting control system}

From Figure 0.1 that shows the results of cooling loads for semi-transparent photovoltaic (STPV) modules compared to single clear glass in all investigated three regions in case of using artificial lighting control system, some critical results for this case are obtained:

1- Due to using the artificial lighting control system, it can be noticed that:

- Increasing the transparency degree or window to wall ratio (WWR) of STPV glazing elements decreases the lighting demand because there is more daylighting entering the space thus using the artificial lighting became less.

- It can be clearly noticed that the case of using single clear glass has the lowest artificial lighting loads due to having the highest transmittance degree.

2- It can be observed clearly that using artificial lighting control system caused emerging some inappropriate STPV combinations to be used due to their bad daylight performance compared with single clear glass $(\mathrm{Sgl} \mathrm{Clr})$ in all three locations. It is not appropriate to use STPV 10\%, 20\%, 30\% and 40\% with WWR $=10 \%$ in all three regions. Also there is no need for implementing STPV $10 \%$ with WWR $=20 \%$ in both Alexandria and Aswan. Besides that in Alexandria, STPV 20\% with WWR $=20$ and STPV $10 \%$ with WWR $=30 \%$ $3-$ are inefficient elements compared with Sgl Clr glass.

4- STPV40\% with WWR $=10 \%$ accomplished the lowest cooling loads in both Cairo and Aswan. It can save $3.3 \%$ and $4.8 \%$ in Cairo and Aswan respectively. While STPV $40 \%$ with WWR $=20 \%$ accomplished the lowest cooling loads in Alexandria. It can save $15.1 \%$ of cooling loads. The element accomplished the lowest cooling loads in Alexandria is more efficient than element that accomplished the lowest cooling loads in both Cairo and Aswan despite of its higher WWR compared with STPV40\% with WWR $=10 \%$. While STPV $40 \%$ with WWR $=100 \%$ achieved the highest cooling load in all three regions. It can save $34.4 \%, 36.4 \%$ and $35.7 \%$ in Cairo, Alexandria and Aswan respectively. It is also noticed that it is more efficient to be used in Alexandria than Aswan and Cairo. 
THE IMPACT OF USING SEMI-TRANSPARENT PHOTOVOLTAIC IN OFFICE BUILDING FACADES ON IMPROVING INDOOR THERMAL PERFORMANCE IN EGYPT

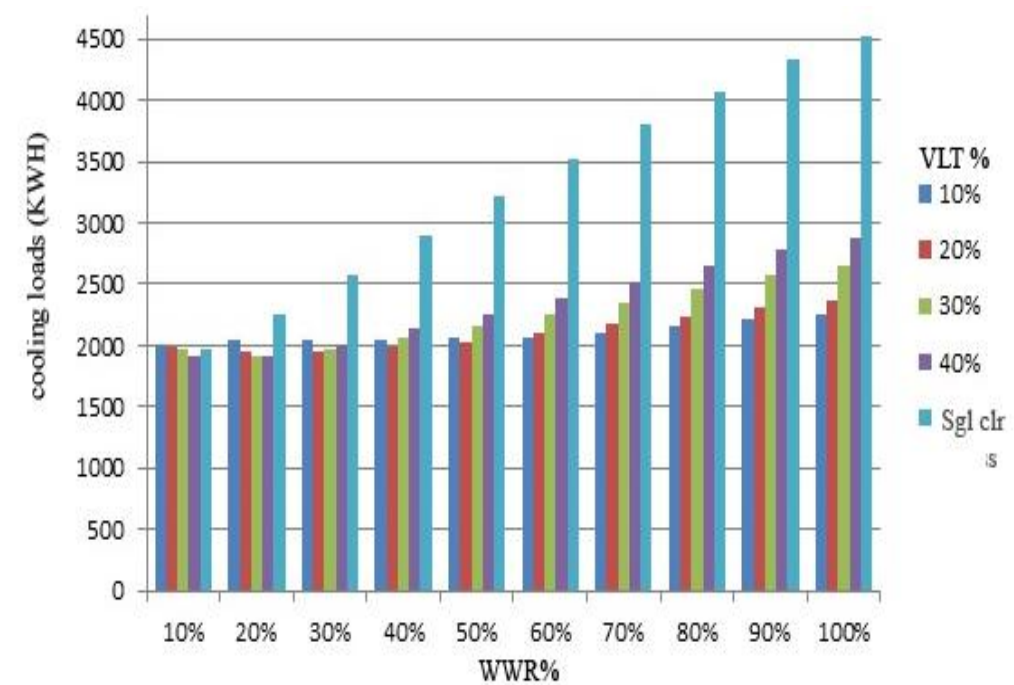

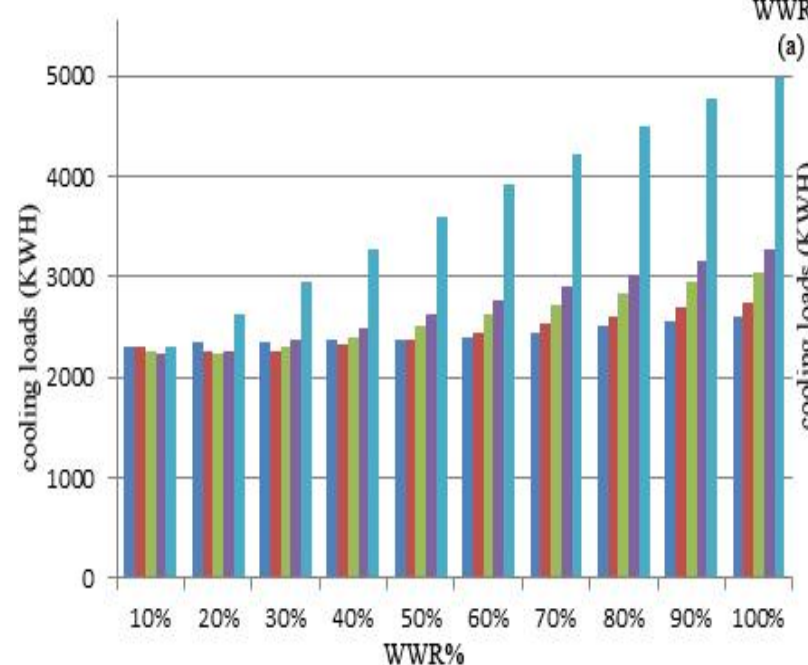

(b)

(a)

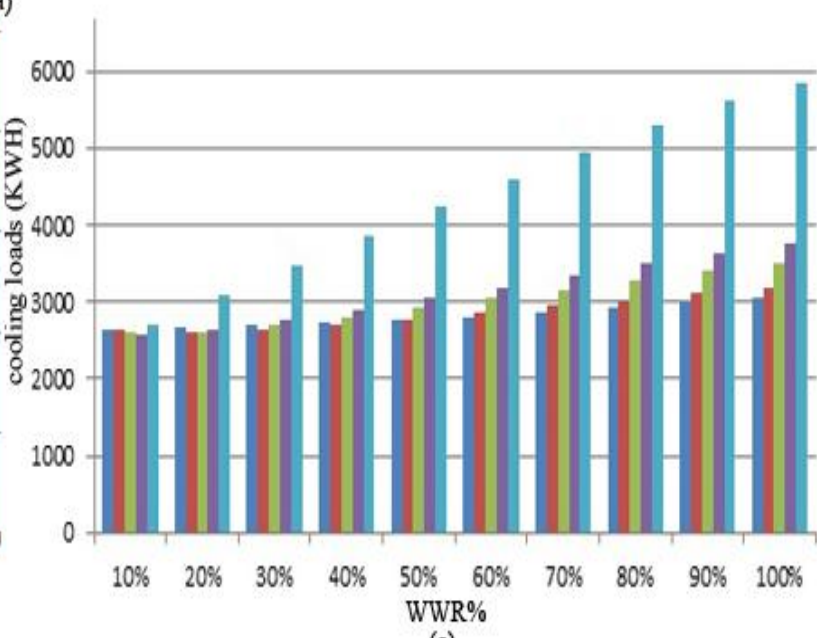

(c)

Figure 0.1 Cooling loads in case of using artificial lighting control system in three regions: (a) Alexandria, (b) Cairo and (c) Aswan.

5- The lowest cooling energy saving is obtained by STPV $10 \%$ with WWR $=20 \%$ in Cairo (can save 10.6\%) while it can be obtained by STPV 30\% with WWR $=20 \%$ in Alexandria (can save 15\%) and by STPV $40 \%$ with WWR=20\% in Aswan (can save 14.8\%). It is also noticed that this element used in Alexandria is more efficient than in Cairo and in Aswan. While the highest cooling energy saving is obtained by STPV $10 \%$ with WWR $=10 \%$ in all three regions. It can save $48.5 \%$ of cooling loads in Cairo, $50.3 \%$ in Alexandria and only $47.9 \%$ in Aswan. It is noticed that this element is more efficient in Alexandria than Cairo and Aswan.

6- As a result of what mentioned before, implementing STPV with the lowest VLT and the highest WWR can save almost half of cooling loads in Cairo and Aswan while it can save more than half of cooling loads in Alexandria. 
THE IMPACT OF USING SEMI-TRANSPARENT PHOTOVOLTAIC IN OFFICE BUILDING FACADES ON IMPROVING INDOOR THERMAL PERFORMANCE IN EGYPT

\section{CONCLUSION}

In conclusion, the thermal performance of semi-transparent photovoltaic (STPV) integrated in office building facades is investigated through finding efficient window to wall ratio (WWR) and visible light transmittance (VLT) in Egypt's climate with taking into account the effect of using the artificial lighting control system. Especially cooling loads are dominant in Egypt due to the high solar heat gains almost throughout the whole year. Compared to single clear glass, this0 study found that integrating STPV in southern façade of office building either in Alexandria, Cairo or Aswan with VLT $=10 \%$ and $\mathrm{WWR}=100 \%$ can save almost half of cooling loads, the highest cooling saving, in both cases of using and not using artificial lighting control system. It can save $48 \%, 46.6 \%$ and $46.3 \%$ in Alexandria, Aswan and Cairo respectively in case of not using artificial lighting control system. It can save 50.3\%, $48.5 \%$ and $47.9 \%$ in Alexandria, Cairo and Aswan respectively in case of using artificial lighting control system. Also it can be concluded that integrating STPV in office building facades in climatic conditions of Alexandria is more efficient than in Aswan and Cairo. Using artificial lighting control system improved the cooling saving rate in all three investigated regions. It also revealed the inefficient STPV elements that are not appropriate to be used due to their bad daylighting performance.

\section{REFERENCES}

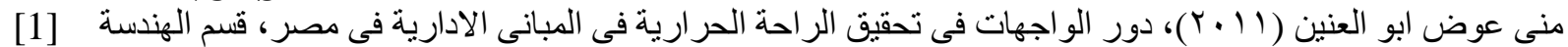

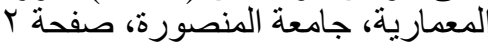

[2] Ministry of electricity and renewable energy. (2018).

http://www.moee.gov.eg/test_new/ST_main.aspx.

[3] Bahaj .A\& James .P\& Jentsch .M. (2007). Potential of emerging glazing technologies for highly glazed buildings in hot arid climates. Energy and buildings, Volume 40(5), P720-721

[4] Khai.N\& Mithraratne.N\& Wittkopf.S. (2012). Semi-Transparent Building-Integrated Photovoltaic Windows: Potential Energy Savings of Office Buildings in Tropical Singapore. 28th Conference, Opportunities, Limits \& Needs Towards an environmentally responsible architecture Lima,P1.

[5] Wah.W\& Shimoda.y\& Nonaka.M\& Inoue.M\& Mizuno.M. (2005). Field Study and Modeling of Semi-Transparent PV in Power, Thermal and Optical Aspects. Asian Architecture and Building Engineering, volume 4 (no.2), P549.

[6] Ng.P. \& Mithraratne. N. \& Kua. H. (2013). Energy analysis of semi-transparent BIPV in Singapore buildings. Energy and buildings, Volume 66, p.280.

[7] Lu .L \& Law . K. (2013). Overall energy performance of semi-transparent single-glazed photovoltaic (PV) window for a typical office in Hong Kong. Renewable energy, Volume 49, p.2 53-254.

[8] L. Olivieri. (2016). Performance of Semi-transparent Photovoltaic Façades. In Pacheco. F. (eds.), Nano and Biotech Based Materials for Energy Building Efficiency. Switzerland: Springer International Publishing. p293, p297.

[9] Miyazaki.T\& Akisawa.A. (March 2005). Energy Savings of Office Buildings by the Use of Semi-Transparent Solar Cells for Windows, Renewable energy, Volume 30(3), p1.

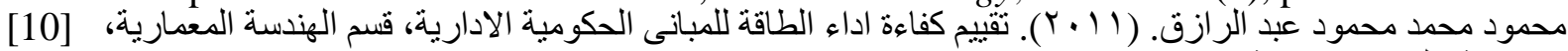

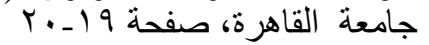

[11] Taman.D. Renewable Energy in Egypt. http://www.academia.edu/18794199/Renewable_Energy_in_Egypt.

[12] Mohamed.A. (2013). Solar energy potentials in Egypt - Solar energy applications as integral multi-functional systems. Sustainable Building Conference, p4.

[13] Time and Date. https://www.timeanddate.com/weather/egypt

[14] Design builder. https://www.designbuilder.co.uk/simulation/ 